\title{
Ocular injuries among industrial welders in Port Harcourt, Nigeria
}

This article was published in the following Dove Press journal:

Clinical Ophthalmology

2 September $201 \mathrm{I}$

Number of times this article has been viewed

\section{B Fiebai \\ EA Awoyesuku}

Department of Ophthalmology, University of Port Harcourt Teaching

Hospital, Port Harcourt, Nigeria
Correspondence: B Fiebai

Department of Ophthalmology,

University of Port Harcourt Teaching

Hospital, Port Harcourt,

Rivers State, Nigeria

Tel +80 52024817

Email bassief@yahoo.com
Background: The purpose of this study was to determine the prevalence and pattern of ocular injuries among industrial welders and rate the use of protective eyewear at work among industrial welders in Port Harcourt. Information from this study will provide a database for effective policy formation on prevention of occupational eye injuries in Port Harcourt Rivers State.

Methods: A cross-sectional survey of ocular injuries and use of protective eyewear among industrial welders in the Port Harcourt local government area of Rivers State, Nigeria, was carried out over a three-month period. Five hundred welders were selected by simple random sampling. Information was obtained using an interviewer-administered questionnaire. All welders were examined in their workshops.

Results: Flying metal chips were the chief source of ocular injury, as reported by 199 (68.15\%) of those who gave a history of work-related eye injury, while arc rays accounted for the remaining $93(31.85 \%)$. There was a high level of awareness of the risk of sustaining an eye injury from welding ( $n=490,98 \%)$, but only $46(15.3 \%)$ of the welders were using protective eyewear at the time of injury.

Conclusion: To minimize ocular injury and promote eye health amongst industrial welders, safety intervention programs, such as awareness campaigns, setting up of targeted programs by the relevant government agencies, and encouragement of locally produced eye protectors is recommended. The involvement of occupational medical practitioners is also strongly recommended.

Keywords: industrial welders, ocular injury, Port Harcourt, preventable blindness, protective eye devices

\section{Introduction}

Ocular injuries are common and constitute a major cause of preventable blindness worldwide. These injuries do not occur as random events, and there is evidence that some individuals are at increased risk because of exposure to hazards and/or inability to avoid or detect hazards. ${ }^{1}$ Some individuals are at increased risk of eye injury as a result of their occupation. Small-scale and large-scale industrial workers constitute a group of individuals at high risk, and welders and other artisans constitute a subset of this group. These workers are exposed to such hazards as flying metal chips, burns in the eye, and injury from radiation. ${ }^{2-4}$ Occupational eye injuries may be very disabling. They occur most frequently in the active years of life, and consequently the vocational and economic consequences are enormous. ${ }^{1}$

Port Harcourt is a major industrial center in Nigeria. It has prospered as the regional headquarters for the petroleum industry. Other industrial activities in Port Harcourt 
include sawmilling, automobile assembly, food canning, and the manufacture of rubber, glass, metal, paper products, cement, and tyres. With increased industrialization, the city has also witnessed a burgeoning of small-scale industries. One such industry is welding, which has served to meet the manufacturing and construction needs of the inhabitants of this city.

The use of personal protective devices has been advocated for and largely implemented in industrialized countries. The increased risk of ocular trauma in small-scale industries as a result of poor organization regarding safety in developing countries has been alluded to by some authors. ${ }^{5}$ Research in Hong Kong on eye injuries in the workplace showed that $85 \%$ of affected individuals did not wear any protective device at the time of injury, despite being aware of these devices. ${ }^{4}$

Port Harcourt is one of the leading industrialized towns in Nigeria, and more industrialized than the towns where similar studies have been done. However, occupational accidents are not routinely reported and analyzed in Nigeria. No work has been done on occupational eye injuries in Port Harcourt. Information from this study will provide a database for effective government policy formation on prevention of occupational ocular injuries in Port Harcourt. Information from this study will also aid in the establishment of an injury surveillance system whereby occupational injuries are routinely reported. Such a system would provide a platform for monitoring of safety policies as well as the trend of visual loss from occupational injury.

\section{Materials and methods}

A cross-sectional study was carried out over a 3-month period from September to November 2006. Five hundred welders were selected by two-stage simple random sampling. Information was obtained using an interviewer-administered questionnaire. All welders were examined in their workshops. Ethical clearance to carry out the study was given by the University of Port Harcourt Teaching Hospital ethical committee.

\section{Results}

The prevalence of work-related ocular injury by history only was $52.2 \%$ (261 welders). Three hundred and one welders $(60.2 \%)$ had either a history or physical evidence of ocular injury (see Figure 1). The chief source of injury as reported by the welders were metal chips and arc rays. Of the 40 welders who had physical evidence of injury, the commonest ocular injuries, in decreasing frequency, included corneal opacity $(n=25,62 \%)$, corneal foreign body $(n=9,22 \%)$, traumatic iritis $(n=3,7 \%)$, conjunctival foreign body $(n=1,3 \%)$, foreign body in the anterior chamber $(n=1,3 \%)$ and traumatic mydriasis ( $\mathrm{n}=1,3 \%$, see Figure 2$)$. There was a high level

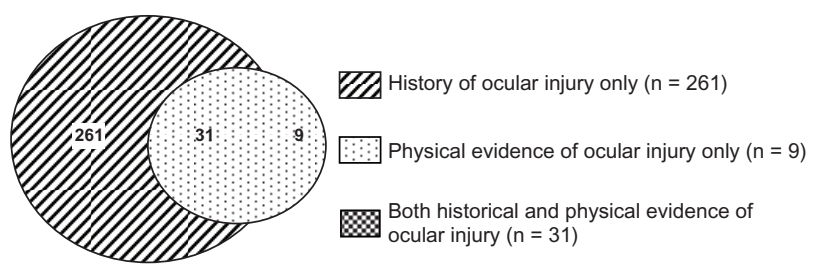

Figure I Venn diagram showing prevalence of historical and physical evidence of ocular injury.

of awareness of the risk of sustaining injury from welding ( $n=490,98 \%)$, but only $46(15.3 \%)$ of the welders were using protective eyewear at the time of injury (see Table 1).

\section{Discussion}

Eye injuries are common, and are a leading cause of preventable unilateral blindness worldwide, with Nigeria being no exception. ${ }^{1}$ In the US, up to 2.4 million ocular injuries are estimated to occur each year. ${ }^{6}$ These ocular injuries could be sustained while at the workplace. Occupational eye injuries are common and avoidable, and despite well publicized standards for industrial protection in developing countries, eye injuries in the workplace are a major cause of socioeconomic damage, morbidity, and disability. ${ }^{7}$ These eye injuries are among the most serious and unpleasant hazards faced by workers. ${ }^{8}$ Welding is one occupation where workers are constantly exposed to ocular trauma as a result of several factors, such as the intense heat from arc welding, explosions from gas welding, and flying pieces of metal from hammering and drilling. ${ }^{2,3}$ In this study, 301 welders $(60.2 \%)$ had either a history or physical evidence of ocular injury, as shown in Figure 1. Studies carried out in eastern Nigeria showed the prevalence of ocular injuries to be $28.5 \%$, which was much higher than the prevalence reported from

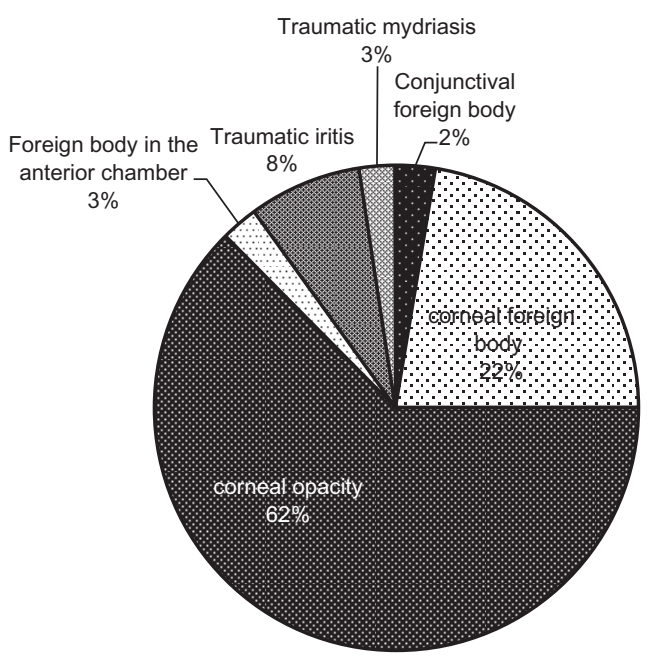

Figure 2 Distribution of ocular injuries seen on examination of 40 welders in the study group. 
Table I Practices regarding use of protective eye wear among the study group*

\begin{tabular}{lll}
\hline Variable & Frequency & Percentage \\
\hline Use of protective eyewear while working $(\mathbf{n}=\mathbf{5 0 0})$ \\
Nil & 16 & 3.2 \\
Yes & 484 & 96.8 \\
Total & 500 & 100 \\
Nil & 255 & 84.7 \\
Yes & 46 & 15.3 \\
Total & 301 & 100 \\
\hline
\end{tabular}

Note: *Use of protective eyewear at the time of injury $(n=30 \mathrm{I})$.

earlier studies in the same region $(6.6 \%) .{ }^{9}{ }^{10}$ The incidence thus appears to have increased over the years rather than decreased, and could be attributed to increasing industrialization. ${ }^{10}$ The chief source of ocular injury as reported by the welders in this study were flying metal chips and arc rays. Similar studies have reported the same sources of injury. ${ }^{9,11}$ Ocular disorders which have been reported in welders include conjunctival degeneration, such as pterygia, pingueculae, and photokeratoconjunctivitis. Others include corneal foreign bodies, burns, cataract, and maculopathy. ${ }^{2,3,8,9,12-14}$ Forty welders in this study had physical evidence of ocular injury. The commonest ocular injuries, in decreasing order of frequency, were corneal opacity $(n=25,62 \%)$, corneal foreign body $(n=9,22 \%)$, traumatic iritis $(n=3,7 \%)$, conjunctival foreign body $(n=1,3 \%)$, foreign body in the anterior chamber $(\mathrm{n}=1,3 \%)$ and traumatic mydriasis $(n=1,3 \%)$.

Welding is commonly used in small-scale and large-scale industries in Nigeria. Whilst advanced processes and safety measures prevail in larger industries, small-scale welders are mostly self-employed. Eye morbidity has been reported to be related to lack of use of eye protection among welders. ${ }^{8,9,15}$ Only $15.3 \%$ of the welders who reported or had physical evidence of injury in this study were using protective eyewear at the time of injury.

\section{Conclusion}

To minimize ocular injury and promote eye health among industrial welders, we recommend that work safety intervention programs should be carried out by eye care providers through leaflets, posters, and television and radio advertisements.
There is a need for the relevant government agencies to design programs for occupational eye safety among industrial workers. Manufacturers should be encouraged by eye care providers to make locally produced eye and face protectors which are suitable, affordable, and available. Periodic systematic assessments should be carried out by health inspectors to assess the efficacy of and compliance with these safety devices. An injury surveillance system should be established by the relevant government agency, to which occupational injuries are routinely reported. Finally, a multidisciplinary approach where occupational medical practitioners are involved in occupational eye safety is strongly recommended.

\section{Disclosure}

The authors report no conflicts of interest in this work.

\section{References}

1. Negrel AD. Eye injuries worldwide. J Comm Eye Health. 1997;10:49-53.

2. Welding hazards. 2006. Available from: http://www.afscme.org/ news/publications/workplace-health-and-safety/fact-sheets/welding. Accessed on August 8, 2011.

3. Ultraviolet, visible and infrared radiation hazards. 2006. Available from: http://www.twi.co.uk/content/faq_radiation.html. Accessed August 8, 2011

4. Yu TS, Liu H, Hui K. A case-control study of eye injuries in the workplace in Hong Kong. Ophthalmology. 2004;111:70-74.

5. Gordon JJ, Darwin CM, Wale R. Ocular trauma at the work place. In: The Epidemiology of Eye Diseases. 1st ed. Cambridge, UK: Cambridge University Press; 1993. 278.

6. Feist RM, Farber MD. Ocular trauma epidemiology. Arch Ophthalmol. 1989;107:503-504.

7. Nicaeus T, Erb C, Rohrbach M, Thiel HJ. An analysis of 148 outpatient treated occupational accidents. Klin Monatsbl Augenheilkd. 1996;209: 7-11. German.

8. Alakija W. Eye morbidity among welders in Benin City in Nigeria Public Health. 1988;102:381-384.

9. Okoye OI, Umeh RE. Eye health of industrial workers in Southeastern Nigeria. West Afr J Med. 2002;21:132-137.

10. Umeh RE. Ocular trauma as seen in UNTH Enugu (retrospective study Jan 1980-May 1986 and prospective study June 1986-Oct 1987). Fellowship dissertation: National Postgraduate Medical College of Nigeria; 1988.

11. Reesal MR, Dufresne RM, Suggett D, Alleyne BC. Welder eye injuries. J Occup Med. 1989;31:1003-1006.

12. Narda R, Magnavita N, Sacco A, Sarnari L, Sani L. Eye diseases in welders: a longitudinal study. Med Lav. 1990;81:399-406.

13. Norn M, Franc C. Long term changes in the outer part of the eye in welders. Acta Ophthalmol (Copenh). 1991;69:382-386.

14. Shaikh TQ, Bhojani FA. Occupational injuries and perception of hazards among road-side welding workers. J Pak Med Assoc. 1991;41:187-188.

15. Ballal SG. Ocular trauma in an iron forging industry in the eastern province, Saudi Arabia. Occup Med (Lond). 1997;47:77-80.
Clinical Ophthalmology

\section{Publish your work in this journal}

Clinical Ophthalmology is an international, peer-reviewed journal covering all subspecialties within ophthalmology. Key topics include: Optometry; Visual science; Pharmacology and drug therapy in eye diseases; Basic Sciences; Primary and Secondary eye care; Patient Safety and Quality of Care Improvements. This journal is indexed on

\section{Dovepress}

PubMed Central and CAS, and is the official journal of The Society of Clinical Ophthalmology (SCO). The manuscript management system is completely online and includes a very quick and fair peer-review system, which is all easy to use. Visit http://www.dovepress.com/ testimonials.php to read real quotes from published authors 